The bed occupancy of $44 \%$ was higher than had been expected in this first year. For the future we estimate that an overall figure of $60 \%$ might be optimal for two reasons. Firstly, it is important to retain the capacity to accept children in need of terminal care or in a crisis at very short notice. Secondly, we need to safeguard "time," which is the most valuable commodity of the house, enabling the children and their families and the staff to have unlimited opportunities to talk and listen.

Although Helen House developed outside the National Health Service, we believe that close liaison with both the hospital and the community services is essential. The design and functioning of the house were empirically based, and the full size and scope of the problem both regionally and nationally are to be determined. It would seem prudent to await the results of research into the magnitude of the problem, the range of facilities currently available, and the best ways of dealing with the needs of such children and their families before planning similar developments elsewhere.
We thank the many people at Helen House who have given their time and energy to the work described here.

\section{References}

1 Burne SR. Hospice care for children. Br Med J 1982;284:1400.

Farrow G. The soothing touch. World Medicine 7 Aug 1982: 39-42.

Mother Frances Dominica. Helen House-a hospice for children. Maternal and Child Health 1982;7:355-9.

Burne SR. A hospice for children in England. Pediatrics 1984;73:97-8.

Ex

Saunders CM, ed. The management of terminal disease. London: Edward Arnold, 1978.

Smith T. Problems of hospices. Br Med f 1984;288:1178-81.

Chapman JA, Goodall J. Helping a child to live whilst dying. Lancet 1980;i:753-6. 1980;5: 144-54

10 Cotton M, Cotton G, Goodall J. A brother dies at home. Maternal and Child Health

1981;6:288-92.
Burton L, ed. Care of the child facing death. London: Routledge and Keegan Paul, 1974

2 Bluebond-Langner M. The private worlds of dying children. Princeton: Princeton University Press,

13 Gyulay J. The dying child. New York: McGraw Hill, 1978.

(Accepted 26 September 1984)

\title{
On the state of the public ill health: premature mortality in the United Kingdom and Europe
}

\author{
JOHN C CATFORD， SHERRY FORD
}

\begin{abstract}
Recently published data on mortality in the European Economic Community and Scandinavia convincingly showed that mortality among men and women aged 45-64 was considerably higher in the United Kingdom than elsewhere. This applied to deaths due to circulatory and respiratory disease, cancer, and all causes. For example, in 1980 in Scotland twice as many, or more, women aged 55-64 per 100000 died of heart disease than in Belgium, Denmark, France, Greece, West Germany, the Netherlands, Norway, and Sweden. Reductions in mortality from all causes during 1950-80 in the United Kingdom did not match those in other countries, such as Finland and France. Whether the public in the United Kingdom knows about its relatively poor mortality state is doubtful. To secure improved funding of appropriate preventive and treatment services directed at reducing premature mortality, public awareness should be raised urgently so that politicians and political parties will respond quickly in a way that the problem demands.
\end{abstract}

\section{Introduction}

Sir Richard Doll in his Harveian oration concluded that medical knowledge had advanced sufficiently that few people need die of disease before the age of $70 .^{1}$ In the United Kingdom it might be thought that such is the case. No particular mention is made in the annual reports of the Chief Medical Officer of the Department of Health that the United Kingdom is experiencing very much worse mortality than its European neighbours. ${ }^{2}$ Acute hospital services, which are in the front line for treatment to avoid premature death,

Wessex Regional Health Authority, Winchester SO22 5DH

JOHN C CATFORD, MRCP, MFCM, regional specialist in community medicine SHERRY FORD, MB, DCH, registrar in community medicine

Correspondence to: Professor J C Catford, University of Wales College of Medicine, Heath Park, Cardiff CF4 4XN. were considered by a royal commission in 1979 to be "generally excellent." ${ }^{3}$ Furthermore, there appears to be little public concern about premature death related to disease, and what interest there is in mortality seems to focus on deaths from violence, suicide, and unusual types of accidents and deaths in infancy. Of the population over the age of 55 , only $3 \%$ are seriously worried about having a heart attack (Health Education Council, unpublished observation, Heart Disease Royal Society of Great Britain Omnibus Survey 1981) and $87 \%$ are either satisfied or very satisfied with the care available for themselves and their families from the National Health Service. ${ }^{4}$ The high degree of satisfaction with the NHS has again been borne out by a recent survey of the Health Education Council and Consumer Association (unpublished observation, 1984), which showed that $83 \%$ of people considered themselves to be very or reasonably healthy and $20 \%$ could not think of one thing to improve their own health.

We set out to examine how the UK compared with the rest of Europe as judged by the avoidance of death between the ages of 45 and 64. This age group accounts for more than two thirds of all deaths under the age of 65 and is clearly a priority group because its members are usually economically productive and have dependent members of their family, both younger and older, to care for.

\section{Method}

The age, sex, and cause specific death rates for 1950 and 1980 were obtained for as many countries as possible in the European Economic Community and Scandinavia. Publications from the World Health Organisation (WHO) giving yearly epidemiological data and vital statistics were studied, and when data were not available approaches were made direct to the WHO or the countries themselves. Suitable data were obtained from the International Classification of Diseases (ICD) chapters for men and women aged 45-54 and 55-64 in 12 countries: Belgium, Denmark, England and Wales, Finland, France, West Germany, Greece, the Netherlands, Northern Ireland, Norway, Sweden, and Scotland. The validity of this type of information from the above countries has not been questioned, ${ }^{5}$ and major misclassifications between ICD chapter headings are unlikely. We could not obtain data for 1980 for the Republic of Ireland or Italy. These countries were therefore excluded from this report, as was Luxembourg because its population is less than $\mathbf{4 0 0 0 0 0}$. International comparisons were made ove time and for groups of diseases. Only the major findings are reproduced here. 
BRITISH MEDICAL JOURNAL VOLUME 289

15 DECEMBER 1984

Results

Tables I-IV present mortalities for the 12 countries for men and women aged 45-54 and 55-64; these values are also expressed as a percentage of the highest mortality overall (Scotland). Mortality from all causes is given as well as from neoplasms (ICD chapter II), diseases of the circulatory system (VII), diseases of the respiratory system (VIII), and external causes, such as injury and poisoning (XVIII). The figure illustrates the differences in mortality between the countries. Mortality from all causes was between two and three times higher in people aged 55-64 than in those aged 45-54.

TABLE I-European mortality per 100000 in 1980 for men aged $45-54$ by cause of death (percentages of Scottish mortality in parentheses)

\begin{tabular}{|c|c|c|c|c|c|}
\hline Country & $\begin{array}{l}\text { Circulatory } \\
\text { system } \\
\text { (ICD } \\
\text { chapter } \\
\text { VII) }\end{array}$ & $\begin{array}{l}\text { Neoplasms } \\
\text { (ICD } \\
\text { chapter } \\
\text { II) }\end{array}$ & $\begin{array}{c}\text { Respiratory } \\
\text { system } \\
\text { (ICD } \\
\text { chapter } \\
\text { VIII) }\end{array}$ & $\begin{array}{c}\text { Injury and } \\
\text { poisoning } \\
\text { (ICD } \\
\text { chapter } \\
\text { XVIII) }\end{array}$ & $\begin{array}{c}\text { All } \\
\text { causes }\end{array}$ \\
\hline $\begin{array}{l}\text { England and Wales } \\
\text { Belgium } \\
\text { Denmark } \\
\text { Finlandt } \\
\text { France } \\
\text { West Germany } \\
\text { Greece } \\
\text { Northern Ireland } \\
\text { The Netherlands } \\
\text { Norwayt } \\
\text { Swedent } \\
\text { Scotland }\end{array}$ & $\begin{array}{l}330 \cdot 8(79) \\
224 \cdot 7(54) \\
231 \cdot 3(55) \\
402 \cdot 2(96) \\
164 \cdot 8(39) \\
245 \cdot 7(57) \\
171 \cdot 7(41) \\
416 \cdot 1(99) \\
223 \cdot 3(53) \\
238 \cdot 4(57) \\
220 \cdot 0(53) \\
418 \cdot 7(100)\end{array}$ & $\begin{array}{l}176 \cdot 2(93) \\
208 \cdot 1(109) \\
168 \cdot 4(88) \\
149 \cdot 0(78) \\
282 \cdot 2(148) \\
181 \cdot 6(95) \\
144 \cdot 1(76) \\
182 \cdot 6(96) \\
180 \cdot 1(95) \\
114 \cdot 8(60) \\
120 \cdot 7(63) \\
190 \cdot 5(100)\end{array}$ & $\begin{array}{l}34 \cdot 2(78) \\
39 \cdot 9(91) \\
18 \cdot 5(42) \\
27 \cdot 7(63) \\
25 \cdot 7(59) \\
19 \cdot 6(45) \\
11 \cdot 0(25) \\
45 \cdot 5(104) \\
12 \cdot 7(29) \\
17 \cdot 0(39) \\
22 \cdot 4(51) \\
43 \cdot 7(100)\end{array}$ & $\begin{array}{c}47 \cdot 1(57) \\
99 \cdot 6(120) \\
105 \cdot 1(126) \\
178 \cdot 5(215) \\
121 \cdot 4(146) \\
94 \cdot 4(114) \\
59 \cdot 3(71) \\
60 \cdot 3(72) \\
44 \cdot 9(54) \\
99 \cdot 3(119) \\
105 \cdot 5(127) \\
83 \cdot 2(100)\end{array}$ & $\begin{array}{l}638 \cdot 6(78) \\
69 \cdot 0(85) \\
644 \cdot 3(79) \\
836 \cdot 5(102) \\
795 \cdot 9(97) \\
711 \cdot 7(87) \\
462 \cdot 4(56) \\
762 \cdot 4(93) \\
544 \cdot 1(66) \\
572 \cdot 2(70) \\
565 \cdot 4(69) \\
820 \cdot 4(100)\end{array}$ \\
\hline
\end{tabular}

ICD = International Classification of Diseases; ${ }^{\star} I C D$ 9th revision; $+\mathrm{ICD} 8$ th revision

TABLE II-European mortality per 100000 in 1980 for men aged 55-64 by cause of death (percentages of Scottish mortality in parentheses)

\begin{tabular}{|c|c|c|c|c|c|}
\hline Country & $\begin{array}{l}\text { Circulatory } \\
\text { system } \\
\text { (ICD } \\
\text { chapter } \\
\text { VII) }\end{array}$ & $\begin{array}{c}\text { Neoplasms } \\
\text { (ICD } \\
\text { chapter } \\
\text { II) }\end{array}$ & $\begin{array}{l}\text { Respiratory } \\
\text { system } \\
\text { (ICD } \\
\text { chapter } \\
\text { VIII) }\end{array}$ & $\begin{array}{l}\text { Injury and } \\
\text { poisoning } \\
\text { (ICD } \\
\text { chapter } \\
\text { XVIII) }\end{array}$ & $\begin{array}{c}\text { All } \\
\text { causes }\end{array}$ \\
\hline $\begin{array}{l}\text { England and Wales } \\
\text { Belgium } \\
\text { Denmark } \\
\text { Finland } \dagger \\
\text { France }^{\star} \\
\text { West Germany }^{\star} \\
\text { Greece }^{\star} \\
\text { Northern Ireland }^{\star} \\
\text { The Netherlands } \\
\text { Norwayt } \\
\text { Swedent } \\
\text { Scotland }\end{array}$ & $\begin{array}{c}946 \cdot 3(82) \\
663 \cdot 1(58) \\
774 \cdot 3(67) \\
1133 \cdot 1(98) \\
427 \cdot 8(37) \\
728 \cdot 5(63) \\
502 \cdot 5(44) \\
1247 \cdot 8(108) \\
669 \cdot 0(58) \\
773 \cdot 5(67) \\
721 \cdot 3(63) \\
1151 \cdot 9(100)\end{array}$ & $\begin{array}{l}561 \cdot 6(89) \\
597 \cdot 2(95) \\
545 \cdot 6(86) \\
506 \cdot 2(80) \\
620 \cdot 5(98) \\
505 \cdot 1(80) \\
457 \cdot 1(72) \\
513 \cdot 2(81) \\
549 \cdot 7(88) \\
392 \cdot 5(62) \\
371 \cdot 7(59) \\
633 \cdot 1(100)\end{array}$ & $\begin{array}{c}147 \cdot 4(84) \\
135 \cdot 6(77) \\
93 \cdot 1(53) \\
112 \cdot 8(64) \\
68 \cdot 2(39) \\
78 \cdot 5(45) \\
61 \cdot 7(35) \\
170 \cdot 2(96) \\
53 \cdot 2(30) \\
57 \cdot 8(33) \\
54 \cdot 2(31) \\
176 \cdot 4(100)\end{array}$ & $\begin{array}{c}58 \cdot 7(64) \\
106 \cdot 8(117) \\
116 \cdot 3(127) \\
182 \cdot 1(200) \\
137 \cdot 8(151) \\
89 \cdot 0(98) \\
71 \cdot 9(79) \\
108 \cdot 5(119) \\
56 \cdot 8(62) \\
98 \cdot 0(107) \\
108 \cdot 3(119) \\
91 \cdot 3(100)\end{array}$ & $\begin{array}{l}1829 \cdot 3(82) \\
1744 \cdot 8(79) \\
1756 \cdot 1(79) \\
2092 \cdot 6(94) \\
1604 \cdot 4(72) \\
1673 \cdot 3(75) \\
1306 \cdot 7(59) \\
2192 \cdot 1(99) \\
1513 \cdot 9(68) \\
1530 \cdot 7(69) \\
1414 \cdot 3(64) \\
2220 \cdot 1(100)\end{array}$ \\
\hline
\end{tabular}

ICD = International Classification of Diseases; ${ }^{*} I C D$ Ninth revision; $\nmid I C D$ eighth revision.
TABLE III-European mortality per 100000 in 1980 for women aged 45-54 by cause of death (percentages of $S$ cottish mortality in parentheses)

\begin{tabular}{|c|c|c|c|c|c|}
\hline Country & $\begin{array}{l}\text { Circulatory } \\
\text { system } \\
\text { (ICD } \\
\text { chapter } \\
\text { VII) }\end{array}$ & $\begin{array}{l}\text { Neoplasms } \\
\text { (ICD } \\
\text { chapter } \\
\text { II) }\end{array}$ & $\begin{array}{l}\text { Respiratory } \\
\text { system } \\
\text { (ICD } \\
\text { chapter } \\
\text { VIII) }\end{array}$ & $\begin{array}{l}\text { Injury and } \\
\text { poisoning } \\
\text { (ICD } \\
\text { chapter } \\
\text { XVIII) }\end{array}$ & $\begin{array}{c}\text { All } \\
\text { causes }\end{array}$ \\
\hline $\begin{array}{l}\text { England and Wales } \\
\text { Belgium }{ }^{\star} \\
\text { Denmark } \\
\text { Finlandt } \\
\text { France } \\
\text { West Germany } \\
\text { Greece } \\
\text { Northern Ireland } \\
\text { The Netherlands } \\
\text { Norwayt } \\
\text { Swedent } \\
\text { Scotland }\end{array}$ & $\begin{array}{r}101 \cdot 4(63) \\
72 \cdot 1(45) \\
78 \cdot 0(48) \\
75 \cdot 6(47) \\
47 \cdot 5(29) \\
74 \cdot 8(46) \\
60 \cdot 8(37) \\
127 \cdot 3(79) \\
63 \cdot 7(39) \\
53 \cdot 3(33) \\
54 \cdot 1(33) \\
161 \cdot 8(100)\end{array}$ & $\begin{array}{l}193 \cdot 9(99) \\
160 \cdot 3(82) \\
221 \cdot 1(113) \\
127 \cdot 9(65) \\
141 \cdot 1(72) \\
159 \cdot 3(81) \\
121 \cdot 9(62) \\
168 \cdot 1(86) \\
151 \cdot 3(77) \\
140 \cdot 8(72) \\
147 \cdot 2(75) \\
195 \cdot 7(100)\end{array}$ & $\begin{array}{r}23 \cdot 2(67) \\
12 \cdot 4(36) \\
17 \cdot 4(50) \\
6 \cdot 8(20) \\
7 \cdot 5(22) \\
10 \cdot 0(29) \\
6 \cdot 9(20) \\
26 \cdot 0(75) \\
5 \cdot 7(17) \\
9 \cdot 8(28) \\
9 \cdot 4(27) \\
34 \cdot 6(100)\end{array}$ & $\begin{array}{l}25 \cdot 9(61) \\
45 \cdot 0(107) \\
64 \cdot 6(153) \\
33 \cdot 3(79) \\
39 \cdot 4(93) \\
34 \cdot 1(81) \\
17 \cdot 5(41) \\
22 \cdot 2(53) \\
21 \cdot 5(51) \\
26 \cdot 4(63) \\
38 \cdot 1(90) \\
42 \cdot 2(100)\end{array}$ & $\begin{array}{l}386 \cdot 5(77) \\
355 \cdot 9(71) \\
447 \cdot 5(89) \\
279 \cdot 8(56) \\
322 \cdot 9(64) \\
352 \cdot 6(70) \\
247 \cdot 6(49) \\
389 \cdot 4(78) \\
288 \cdot 6(57) \\
273 \cdot 8(55) \\
295 \cdot 7(59) \\
502 \cdot 2(100)\end{array}$ \\
\hline
\end{tabular}

ICD = International Classification of Diseases; ${ }^{\star} I C D$ ninth revision; $\nmid I C D$ eighth revision

TABLE IV-European mortality per 100000 in 1980 for women aged 55-64 by cause of death (percentages of Scottish mortality in parentheses)

\begin{tabular}{|c|c|c|c|c|c|}
\hline Country & $\begin{array}{l}\text { Circulatory } \\
\text { system } \\
\text { (ICD } \\
\text { chapter } \\
\text { VII) }\end{array}$ & $\begin{array}{c}\text { Neoplasms } \\
\text { (ICD } \\
\text { chapter } \\
\text { II) }\end{array}$ & $\begin{array}{l}\text { Respiratory } \\
\text { system } \\
\text { (ICD } \\
\text { chapter } \\
\text { VIII) }\end{array}$ & $\begin{array}{c}\text { Injury and } \\
\text { poisoning } \\
\text { (ICD } \\
\text { chapter } \\
\text { XVIII) }\end{array}$ & $\begin{array}{c}\text { All } \\
\text { causes }\end{array}$ \\
\hline $\begin{array}{l}\text { England and Wales }{ }^{\star} \\
\text { Belgium }{ }^{\star} \\
\text { Denmark } \\
\text { Finland } \dagger \\
\text { France }{ }^{\star} \\
\text { West Germany } \\
\text { Greece }^{\star} \\
\text { Northern Ireland } \\
\text { The Netherlands } \\
\text { Norwayt } \\
\text { Swedent } \\
\text { Scotland }\end{array}$ & $\begin{array}{l}359 \cdot 1(70) \\
236 \cdot 2(45) \\
262 \cdot 1(51) \\
291 \cdot 0(57) \\
141 \cdot 1(27) \\
245 \cdot 7(48) \\
235 \cdot 1(46) \\
504 \cdot 9(98) \\
206 \cdot 1(40) \\
209 \cdot 5(41) \\
204 \cdot 3(40) \\
515 \cdot 5(100)\end{array}$ & $\begin{array}{l}417 \cdot 2(93) \\
312 \cdot 0(69) \\
431 \cdot 1(96) \\
281 \cdot 5(62) \\
274 \cdot 8(61) \\
344 \cdot 7(76) \\
245 \cdot 9(55) \\
432 \cdot 7(96) \\
316 \cdot 4(70) \\
304 \cdot 0(68) \\
329 \cdot 9(73) \\
450 \cdot 7(100)\end{array}$ & $\begin{array}{c}71 \cdot 6(85) \\
27 \cdot 5(33) \\
54 \cdot 2(65) \\
30 \cdot 5(36) \\
19 \cdot 1(23) \\
25 \cdot 8(31) \\
29 \cdot 6(35) \\
110 \cdot 7(132) \\
17.5(21) \\
25 \cdot 8(31) \\
34 \cdot 6(41) \\
83.8(100)\end{array}$ & $\begin{array}{l}32 \cdot 4(70) \\
68 \cdot 0(147) \\
65 \cdot 2(141) \\
43 \cdot 3(94) \\
52 \cdot 6(114) \\
43 \cdot 1(93) \\
25 \cdot 5(55) \\
33 \cdot 0(71) \\
29 \cdot 9(65) \\
29 \cdot 2(63) \\
48 \cdot 2(104) \\
46 \cdot 3(100)\end{array}$ & $\begin{array}{r}927 \cdot 5(80) \\
783 \cdot 9(64) \\
947 \cdot 6(78) \\
744 \cdot 7(61) \\
634 \cdot 9(52) \\
797 \cdot 9(65) \\
673 \cdot 0(55) \\
1193.9(98) \\
676 \cdot 5(55) \\
665 \cdot 1(54) \\
708 \cdot 5(58) \\
1223 \cdot 0(100)\end{array}$ \\
\hline
\end{tabular}

ICD = International Classification of Diseases; ${ }^{\star} I C D$ ninth revision; $f I C D$ eighth revision.

The data clearly showed that Scotland, Northern Ireland, and England and Wales had some of the highest premature death rates in Western Europe, and the difference between countries was pronounced. In men and women in both age groups mortality from all causes in the Netherlands, Norway, Sweden, and Greece was two thirds or less that in Scotland. Mortality from circulatory and respiratory diseases showed even more striking differences: in eight of the nine non-UK countries mortality among women was less than half of that in Scotland and among men it was less than two thirds. In Finland mortality from circulatory diseases was lower than

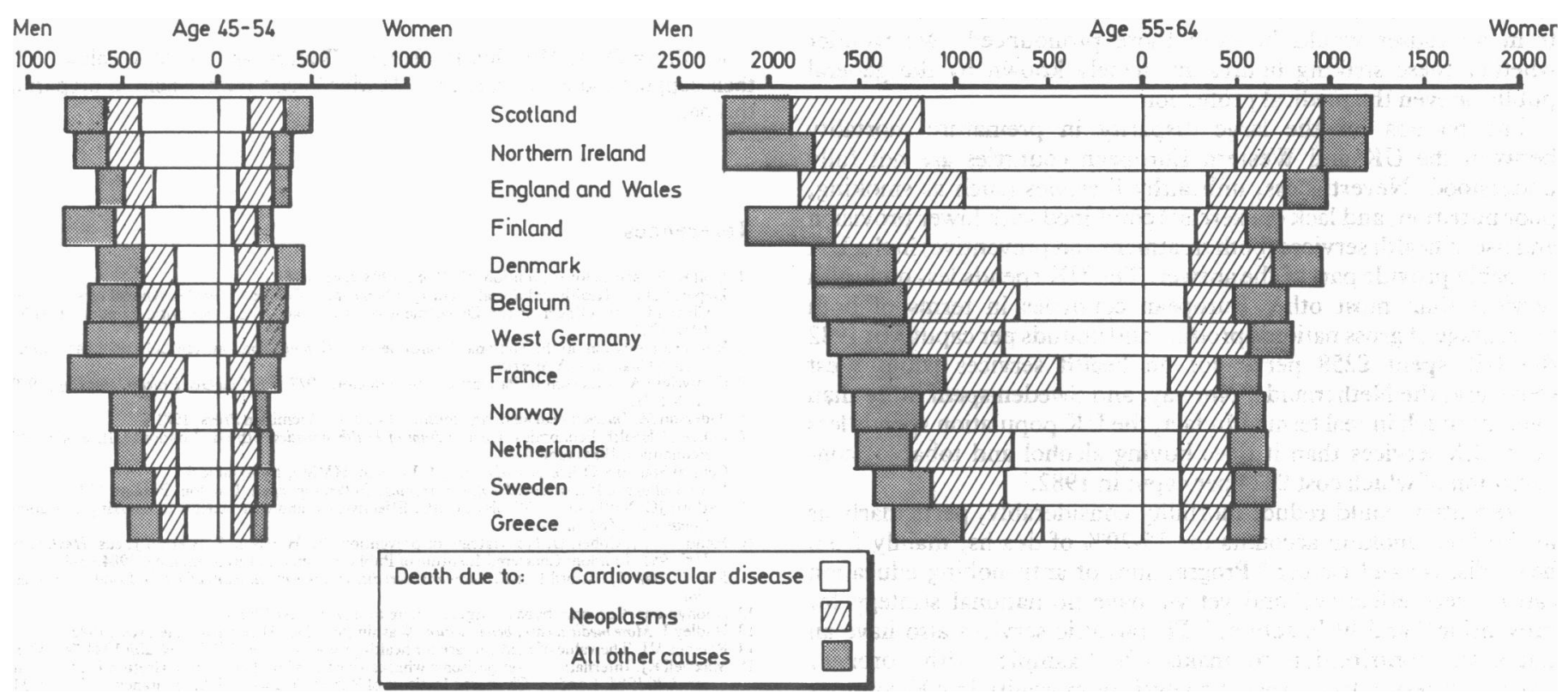

European mortality per 100000 by age, sex, and cause, 1980 . 
that in Scotland and Northern Ireland for men and lower than that in the whole of the UK for women.

A similar picture emerged for neoplasms, but the differences were less extreme. Nevertheless, mortality among men and women in both age groups in at least one country was two thirds that in Scotland. The UK, however, compared favourably with many other European countries regarding deaths from injuries and poisonings, which were predominantly accidental. England and Wales had some of the lowest figures for mortality caused by injuries, which reduced the difference between the UK and Europe in mortality from all causes. care had an appreciable impact on mortality. ${ }^{13}$ After controlling for other factors, such as income, education, marital state, employment, consumption of cigarettes, and disability, he found that $c$ mortality was lower in cohorts with greater estimated use of medical $\overline{\widehat{C}}$ care. For example, a $10 \%$ increase in expenditure on medical care by white Americans aged 45-64 was estimated to reduce mortality by $3 \cdot 2 \%$ in men and $1 \cdot 3 \%$ in women.

Prevention is likely to be more cost effective than treatment in lowering mortality. Treatment in turn appears to be more cost

TABLE V-Comparison of mortality from all causes per 100000 in 1950 and 1980

\begin{tabular}{|c|c|c|c|c|c|c|c|c|c|c|c|c|}
\hline \multirow[t]{2}{*}{ Country } & \multicolumn{3}{|c|}{ Men aged 45-54 } & \multicolumn{3}{|c|}{ Women aged 45-54 } & \multicolumn{3}{|c|}{ Men aged 55-64 } & \multicolumn{3}{|c|}{ Women aged 55-64 } \\
\hline & 1950 & 1980 & $\%$ improvement & 1950 & 1980 & $\%$ improvement & 1950 & 1980 & $\%$ improvement & 1950 & 1980 & $\%$ improvement \\
\hline $\begin{array}{l}\text { England and Wales } \\
\text { Finland } \\
\text { France } \\
\text { Scotland }\end{array}$ & $\begin{array}{r}827 \cdot 5 \\
1309 \cdot 1 \\
991 \cdot 2 \\
1027 \cdot 8\end{array}$ & $\begin{array}{l}638 \cdot 6 \\
836 \cdot 5 \\
795 \cdot 9 \\
820 \cdot 4\end{array}$ & $\begin{array}{l}23 \\
36 \\
20 \\
20\end{array}$ & $\begin{array}{l}529 \cdot 9 \\
592 \cdot 6 \\
566 \cdot 2 \\
625 \cdot 7\end{array}$ & $\begin{array}{l}386 \cdot 5 \\
279 \cdot 8 \\
322 \cdot 9 \\
502 \cdot 2\end{array}$ & $\begin{array}{l}27 \\
53 \\
43 \\
20\end{array}$ & $\begin{array}{l}2251 \cdot 5 \\
3077 \cdot 1 \\
2157 \cdot 1 \\
2530 \cdot 8\end{array}$ & $\begin{array}{l}1829 \cdot 3 \\
2092 \cdot 6 \\
1604 \cdot 4 \\
2220 \cdot 1\end{array}$ & $\begin{array}{l}19 \\
32 \\
26 \\
12\end{array}$ & $\begin{array}{l}1260 \cdot 8 \\
1484 \cdot 5 \\
1215 \cdot 4 \\
1540 \cdot 0\end{array}$ & $\begin{array}{r}972 \cdot 5 \\
744 \cdot 7 \\
634 \cdot 9 \\
1223 \cdot 0\end{array}$ & $\begin{array}{l}23 \\
50 \\
48 \\
21\end{array}$ \\
\hline
\end{tabular}

In 1950 the four European countries with the highest mortality from all causes for both age groups and sexes were England and Wales, Finland, France, and Scotland. (Data were not available for Northern Ireland, Greece, Norway and Belgium). Table $\mathrm{V}$ shows the changes in mortality between 1950 and 1980 . Although mortality fell in all four countries, the advances were notably better in France and Finland in terms of both real and percentage changes. For example, in 1950 mortality from all causes in men aged 55-64 was 22\% higher in Finland than Scotland, but by 1980 it was $6 \%$ lower, in women aged 55-64 mortality was about the same in both countries in 1950, but by 1980 it was 39\% lower in Finland than Scotland.

\section{Discussion}

Judging by these mortality figures, the UK is clearly not enjoying the same level of health as its European neighbours. Over the past 30 years progress in reducing premature mortality has not matched that of other countries. In populations of equivalent sizes, for every 10 women aged 55-64 dying of heart disease in Scotland or Northern Ireland seven will die in England and Wales, five in Denmark, Belgium, Germany, and Greece, and four or fewer in France, the Netherlands, Norway, and Sweden. For every 10 men aged 55-64 dying of heart disease in Scotland or Northern Ireland eight will die in England and Wales, six in Belgium, Germany, the Netherlands, and Sweden, and four in France and Greece. If it were not for our relatively low mortality from accidents the differences in mortality from all causes would be even more pronounced. We wonder whether these striking figures are widely known by the general public or even the medical profession.

The reasons for the large disparity in premature mortality between the UK and Western European countries are not fully understood. Nevertheless, unhealthy lifestyles (such as smoking, poor nutrition, and lack of exercise) combined with lower provision and use of health services (both treatment and preventive) in the UK probably provide part of the answer. The UK spends less on health services than most other European countries in terms of both percentage of gross national product and pounds per caput. ${ }^{6}$ In 1982 the UK spent $£ 258$ per caput on health services while West Germany, the Netherlands, Norway, and Sweden spent more than twice as much in real terms. ${ }^{6}$ In fact, the UK population spends less on health services than it does buying alcohol and tobacco, consumption of which cost $£ 324$ per caput in $1982 .^{?}$

Prevention could reduce mortality considerably, particularly as in the UK smoking accounts for $15-20 \%$ of deaths, mainly from heart disease and cancer. ${ }^{8}$ Programmes of antismoking education can be very effective, ${ }^{9}$ and yet we have no national strategy for prevention ${ }^{10}$ and little action. ${ }^{11}$ Therapeutic services also have an important contribution to make-for example, with coronary bypass surgery. ${ }^{12}$ In his recent analysis of mortality in 400 counties of the United States Hadley clearly showed that the use of medical effective than increasing the income of the poor. ${ }^{13}$ This is because the cost benefit ratio, particularly for prevention of smoking, is so great. ${ }^{9}$ As Roemer argued, however, ${ }^{14}$ it would be extremely counterproductive to polarise the wings of health care, particularly as a partnership is so often required for the delivery of preventive and treatment services. It is too often forgotten that prevention ranges from the promotion of healthy lifestyles, through prevention of specific diseases and early detection of disease, to rehabilitation and the prevention of disability and social handicap.

Surely more resources for appropriate preventive and treatment services are required if Britain is to enjoy the level of health currently experienced by its European neighbours. The country could afford this development if it wanted to, but it seems that the public and politicians do not consider the benefits to be worth the cost. This may be because they have been lulled into a false sense of complacency about the state of the nation's health. If the public was made more aware of our health state in relation to other European countries action might follow. This was how the Finnish health services secured additional resources for preventive services. Although we can be reasonably satisfied with our performance in view of our comparatively low input of resources, ${ }^{15}$ we should not fail to make clear that we have a long way to catch up. Perhaps the next report of the Chief Medical Officer "on the state of the public health" might set a lead in raising public awareness about this country's relatively poor health performance in premature mortality.

We thank Dr M Murphy, Professor E Waters, and Dr M Woolaway for their support and advice and Miss $M$ Macdonald for her help in preparing this paper.

\section{References}

1 Doll R. Prospects for prevention. Br Med J 1983;286:445-53.

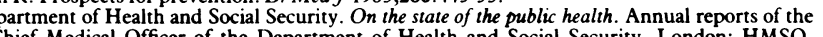
1977-1982.
Royal Commission on the National Health Service. Report. London: HMSO, 1979:145. (Cmnd $\mathrm{W}$
7615.) (Chairman, A Merrison.)

Cartwright A, Anderson R. Patients and their doctors 1977. J R Coll Gen Pract [Occas Pap] 1979;

No 8:1-21.
5 Alderson M. International mortality statistics. London: Macmillan Press, 1981. Alderson M. Intermational mortality statistics. London: Macmillan Press, 1981.
Office of Health Economics. Compendium of health statistics. 5th ed. London: Office of Health
Economics, 1984; table 2.2.

Central Statistics Office. Social trends 14. London: HMSO, 1984; table 6.7. Cord JC, Nutbeam D, Woolaway MC. Effectiveness and cost-benefits of smoking education. Community Med (in press).

10 Henderson J, Cohen D. No strategy for prevention. In: Harrison A, Gretton J, eds. Health care UK 1984. London: Chartered Institute of Public Finance and Accountancy, 1984:63-8. Rose G, Bail

12 Anonymous. Coronary bypass surgery-here to stay. Lancet $1983 ; \mathrm{i}: 197-8$.

Hadey J. More medical care, better health? Washington, DC: Urban Institute Press, 1982.

14 Roemer MI. The value of medical care for health promotion. Am f Public Health 1984;74:243-8. Maxwell RJ. International comparisons: what can we learn? In: Harrison A, Gretton J, eds. Healt care UK 1984. London: Chartered Institute of Public Finance and Accountancy, 1984:125-31.

(Accepted 31 August 1984) .



\section{.}

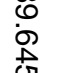

